\title{
THE GENUS Platylomia Stål, 1870 (Hemiptera: Cicadidae) FROM VIETNAM, WITH DESCRIPTION OF ONE NEW SPECIES AND KEY TO SPECIES
}

\author{
Pham Hong Thai ${ }^{1 *}$, Jérôme Constant ${ }^{2}$ \\ ${ }^{1}$ Vietnam National Museum of Nature, VAST, *phamthai@ vnmn.vast.vn \\ ${ }^{2}$ Royal Belgian Institute of Natural Sciences, Belgium
}

\begin{abstract}
The Platylomia radha species group is proposed within the genus Platylomia Stål, which includes one new species, Platylomia duffelsi sp. nov., from the north Vietnam. Synonymic lists for the four species of Platylomia from Vietnam are provided. A key to the four Platylomia species: P. bocki (Distant), P. duffelsi sp. nov., P. malickyi Beuk, and P. operculata Distant from Vietnam is provided. Photos of the adult, illustrations of the male genitalia, a distribution map and biological data are also given.
\end{abstract}

Keywords: Auchenorrhyncha, Platylomia, cicada, morphology, distribution.

\section{INTRODUCTION}

The genus Platylomia belongs to the subtribe Dundubiina of the tribe Cicadini in the subfamily Cicadinae [10]. Beuk (1998) [2] proposed the Platylomia radha species group with six species: P. rahda, P. bocki, P. malickyi, $P$. bivocalis, $P$. ficulnea, $P$. pendleburyi and providing a key to the species.

The $P$. radha group is characterized by the abdomen 1.2-1.5 times as long as head and thorax together. Sternite VII with very shallow to rather deep posteromedial emargination. Operculum rather variable in length and shape, reaching from anterior margin of fifth to just beyond posterior margin of seventh abdominal segment. Uncus lobes short and gradually narrowing distally or first narrowing and then some what broadening distally; distal margin ranging from smooth and sinuous to adorned with lobule or triangular projections; lateral margin distally sometimes adorned with dorsal (inner) flange or with one or more small triangular projections (Beuk, 1998) [2].

The group at present comprises six species: P. operculata, P. bocki, P. malickyi, P. bivocalis, $P$. ficulnea and $P$. pendleburyi distributed with certainty in India, Bhutan, Nepal, Mianma, Thailand, Laos, Cambodia, Vietnam, China and Taiwan.

This paper presents the description of one new species of the Platylomia radha group from Cao Bang province, Northern Vietnam.

\section{MATERIALS AND METHODS}

Three males of a new Platylomia duffelsi species were collected from the Phia Oac-Phia Den Nature Reserve, Nguyen Binh district, Cao Bang Province, in Northern Vietnam. The type specimens of this new species are deposited in the Vietnam National Museum of Nature, Hanoi, Vietnam.

Nomenclature for family, subfamily and tribal classification follows that of Lee (2008) [10]. Morphological terminology follows that of Moulds (2005) [12]. The genitalia of all the male specimens have been examined. The male genitalia of the holotype were examined and photographed using a dissecting microscope (Leica EZ4 HD). A distribution map produced by the software CFF 2.0 [1] and photos of habitus are provided.

\section{RESULTS AND DISCUSSION}

\section{Taxonomy}

Family Cicadidae

Subfamily Cicadinae

\section{Tribe Cicadini}

\section{Subtribe Dundubiina}

\section{Genus Platylomia Stål, 1870}

Platylomia Stål, 1870: 708 (as a subgenus of Cosmopsaltria). Type species: Cicada 
flavida Guérin-Méneville, 1834 (Java and Sumatra).

Diagnosis. Large-sized; eyes much prominent laterally; head including eyes wider than base of mesonotum; frontoclypeus substantially prominent anteriorly, longer than vertex in middorsal length; pronotum distinctly shorter than mesonotum excluding cruciform elevation; outer dilatation of pronotum not developed, anterolateral margin dentate; tymbal mostly concealed with tymbal covering; male abdomen cylindrical, distinctly longer than distance from head to cruciform elevation; ovipositor extending beyond pygofer; fore femur with two big and a small spines on under surface; male operculum generally much elongated, with apex rounded or acuminated.

Distribution. Oriental and Australian regions.

\section{Key to the Vietnamese species of the genus Platylomia}

1 Male operculum reaching posterior margin sternite $\mathrm{V}$, apex rounded.

- Male operculum extending passing sternite V, apex acute angled; lobe pygofer prominent clearly and acute angled. P. operculata

2 Basal lobes of pygofer well developed and distinctly prominent.................. duffelsi sp.nov.

- Basal lobe of pygofer not well developed and distinctly prominent

3 Apical lobe uncus not prominent, only with small node in exterior margin................. bocki

- Apical lobe uncus prominent clearly, with two small nodes in exterior margin.........P. malickyi

\section{Platylomia bocki (Distant, 1882)} (Figs. 3B, 4B, 5B)

Dundubia bocki Distant, 1882: 159 [TL: Indochina].

Platylomia bocki; Beuk, 1998: 159; Pham, 2004: 64; Sanborn et al., 2007: 23; Lee, 2008: 17; Pham \& Yang, 2009: 15.

Material examined: Phu Tho: 19, Lap, Xuan Son NP, 300-500 m, Cic0624, 15.vi.2004,

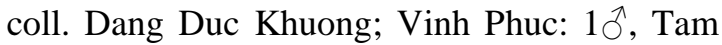
Dao NP, 1,000 m, 25-28.vii.2011, coll. Pham Hong Thai; Ninh Binh: $3 \hat{\jmath}$, Cuc Phuong NP, 250m, 30.iv.2004, vi.2004, v.2006; Thanh Hoa: 2 $\widehat{0}$, Xuan Hoa, Nhu Xuan, 150-200 m, Ho.1.0177, Ho.1.0237, light trap, 29.v.2008, coll. Hoang Vu Tru; Quang Tri: $1 \hat{\delta}$, 1우, Peke pass, ABung, Dakrong, $620 \mathrm{~m}$, Ho.1314, Ho.1315, light trap, 5.v.2005; Quang Nam: 10, Lo Xo pass, Phuoc My, Phuoc Son, 1,025 m, Ho.0981, 1.v.2005; Kon Tum: 10̊, Ngoc Linh NR, vi.2006; Gia Lai: 19, headquarters of Kon Ka Kinh NP, 820 m, Ho.2.0085, light trap, 31.v.2011, coll. Hoang Vu Tru; 19, AYun, Mang Yang, 1,013 m, Ho.2.0012, light trap, 2.vi.2011, coll. Hoang Vu Tru; Lam Dong: $5 \hat{\jmath}$, Dambri, 800 m, v.2003, coll. Ta Huy Thinh.

Distribution: Vietnam (Phu Tho, Vinh
Phuc, Ninh Binh, Thanh Hoa, Quang Tri, Quang Nam, Gia Lai, Kon Tum, Lam Dong), South China, Laos, Cambodia and Thailand.

\section{Platylomia duffelsi sp. nov.}

(Figs. 1, 2, 3D, 4D, 5A)

Etymology: The species is dedicated to Dr. Hans Duffels in acknowledgment for his considerable contributions to cicada systematics.

Material examined: Holotype (male): VIETNAM: Phia Oac-Phia Den Nature Reserve, Nguyen Binh, Cao Bang, 10.ix.2013, coll. Pham Hong Thai (VNMN).

Paratypes (2 males): the same data as holotype (VNMN).

\section{Description}

Head: including eyes wider than mesonotum at base; vertex width broader than length, pale yellow-brown, with a broad pair of oblique black spots between eyes and anterior arm of epicranial, fascia on posterior margin eyes against anterior margin of pronotum, two oblique large fasciae around ocelli black; supraantennal plate slightly curved; frons black; postclypeus with two large black spots in dorsal view; gena pale yellow-brown; lorum pale 
yellow with dense white lanugo, area against anteclypeus black; postclypeus prominent, greenish-yellow, with black longitudinal fascia in centre, and bifurcate towards apex of head;

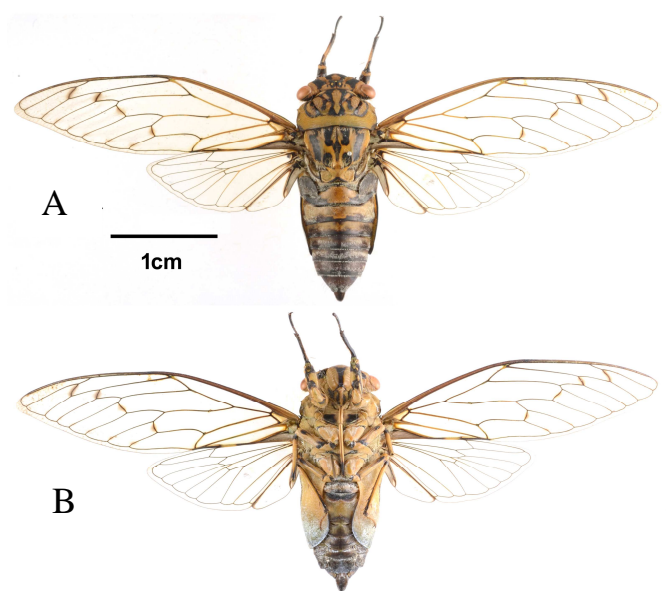

Figure 1. Platylomia duffelsi sp. nov.

A. dorsal view of male; $B$. ventral view of male.
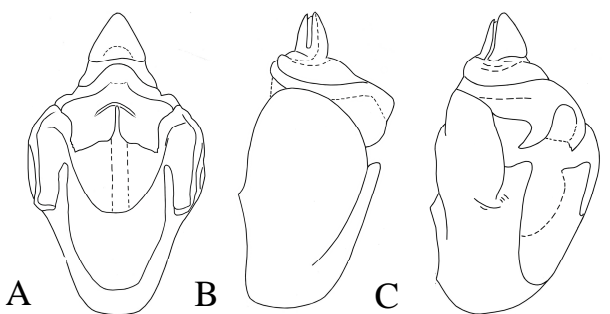

Figure 2. Platylomia duffelsi sp. nov.

A. male genitalia in ventral view; B. male genitalia in lateral view; C. male genitalia lateroventral in view.

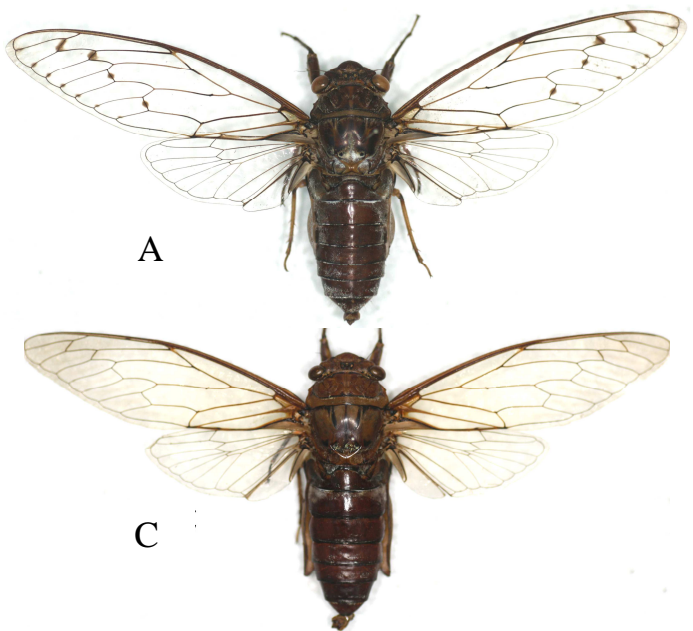

A
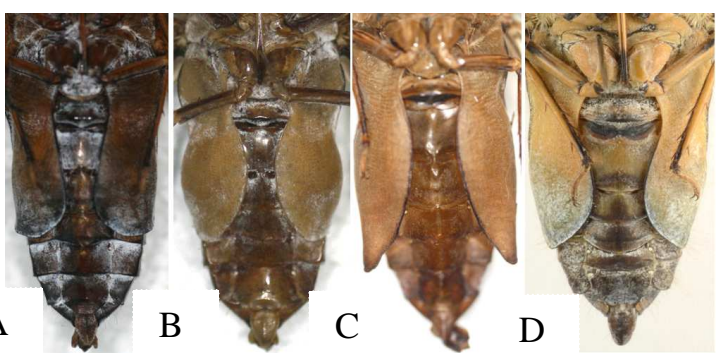

Figure 3. Abdomen and operculum of Platylomia species from Vietnam in ventral view: (A) P. malickyi; (B) P. bocki; (C). P. operculata; (D). Platylomia duffelsi sp. nov.

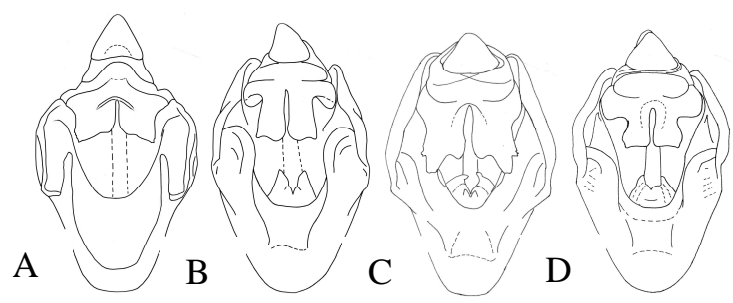

Figure 5. Male genitalia of Platylomia species from Vietnam in ventral view: (A). Platylomia duffelsi sp. nov.; (B). P. bocki (after Beuk, 1998); (C). P. malickyi (after Beuk, 1998); (D). P. operculata (after Beuk, 1998).

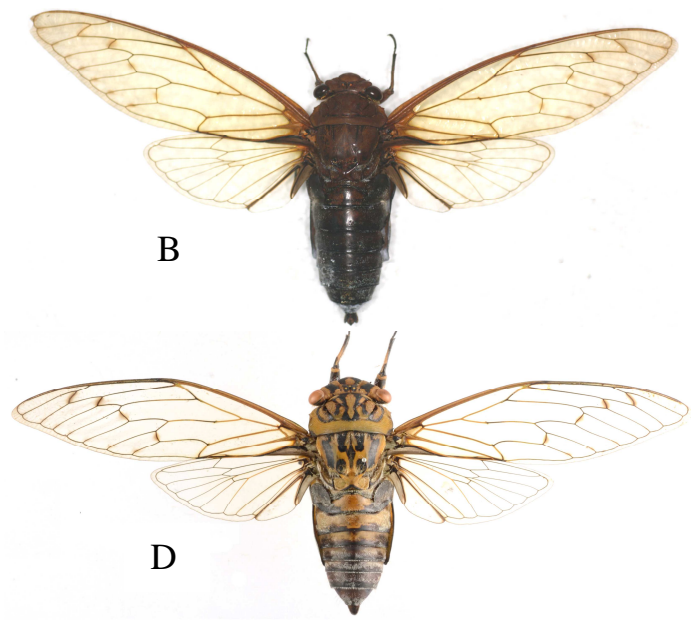

Figure 4. Platylomia species from Vietnam in dorsal view:

(A). P. malickyi; (B). P. bocki; (C). P. operculata; (D). Platylomia duffelsi sp. nov. 
Thorax: pronotum pale yellow-brown, with pair of central longitudinal fasciae, two oblique small fasciae between paramedian fissure and lateral fissure, surround of paramedian fissure and lateral fissure black; pronotal collar slightly tinged with green, with small, distinct, tooth on lateral margin pronotal collar, posterior margin black; mesonotum pale yellow-brown, with five black fasciae, median fascia anteriorly fairly narrow, not reaching anterior margin of mesonotum, two longitudinal fascia on parapsidal suture with apex hook-like, two fasciae slightly curved close to inner margin of lateral sigilla, scutal depression with black point, two black markings on anterior margin; cruciform elevation pale yellow-brown with anterior branches of cruciform elevation with apical black, posterior margin black; thorax in ventral view pale yellow-brown, with dense lanugo and white waxy, basisternum 2, 3 with black marking.

Wings: fore and hind wings hyaline, with veins dark brown, fore wings slightly tinged and spotted with infuscations on $\mathrm{m}, \mathrm{r}-\mathrm{m}$ and $\mathrm{m}-\mathrm{cu}$, on RA2, RP, M1, M2, M3, M4, and CuA1 brown-black.

Legs: all legs yellow-brown, with markings as follows: fore leg with base of trochanter, two longitudinal fascia on femur in dorsal and ventral view, apex and base of femur, tibiae and tarsus black, primary spine of fore femur the same size; middle leg with base trochanter, base and apex of femur, a longitudinal fascia in lateral view of femur, base and one third towards apex of tibia, and tarsus black; hind leg with base femur and tibia, a longitudinal of tibia in ventral view black; pretarsal claw of all leg black.

Abdomen: longer than distance from head to cruciform elevation, pale yellow-brown in dorsal view, tergite1 black, anterior and posterior margin of tergite 2,3 black; posterior margin of tergite 4-8 black, tergite 8 brownishblack; timbal cover large, black, and covering timbal completely; grey with white waxy in ventral view, posterior margin sternite III-VI brown-black, sternite VII, VIII brown-black.

Operculum: pale green-yellow with black margin surround except inner margin at haft base, reaching pass posterior margin of abdominal segment $7^{\text {th }}, 4$ times as long as maximum width distal of constriction; medial margin distal of constriction convex near apex, apex of operculum lateral of midline gullyshaped with surface concave along both medial and lateral margin and then divergent from abdomen.

Genitalia $\delta^{\lambda}$ : pygofer yellow-brown, with long as longer than broad, lateral margin at one second parallel in ventral view; uncus bifurcate, pale brown, apex brown-black, lateral margin of uncus lobe slightly convex basally and weakly concave at first third, upper lobe of pygofer apically rounded without protrusion, basal lobe of pygofer with converging parallel ridges, apical distinct prominent, rounded.

Measurements in mm: (3 males): body length: 40.7-42.2; fore wing length: 48.7-51.0; fore wing width: 15.1-15.5; head width: 14.014.5; pronotum width: 14.4-14.9.

Biology: This species was collected by light trapping at high mountain in the secondary forest at an altitude between 1,500 meters.

Distribution: North Vietnam (Cao Bang province).

\section{Platylomia malickyi Beuk, 1998} (Figs. 3A, 4A, 5C)

Platylomia malickyi Beuk, 1998: 164 [TL: Thailand; Vietnam; Laos; Myanmar]; Boulard, 2003: 185; Sanborn et al., 2007: 23; Lee, 2008: 17; Pham \& Yang, 2009: 15.

Material examined: Gia Lai: $1 \hat{\partial}$, headquarters of Kon Ka Kinh NP, 820 m, Ho.2.0113, light trap, 3.vi.2011, coll. Hoang Vu Tru; 10 , the same locality, Ho.2.0105, light trap, 4.vi.2011, coll. Ta Huy Thinh; 3 $\hat{\jmath}, 1$, AYun, Mang Yang, 880 m, Ho.2.0094Ho.2.0097, light trap, 5.vi.2011, coll. Hoang Vu Tru; $1 \widehat{\jmath}$, Kon Loc 1, Dak Roong, Kbang, 1,060 m, Ho.2.0003, light trap, 6.vi.2011, coll. Hoang

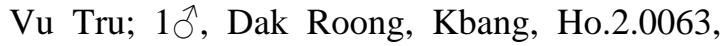
light trap, 8.vi.2011, coll. Tran Thieu Du; 19, Dak Jo Ta, Mang Yang, Ho.2.0014, 9.vi.2011, coll. Hoang Vu Tru. 
Distribution. Vietnam (Gia Lai, Lam Dong), South China (Yunnan), Myanmar, Laos and Thailand.

\section{Platylomia operculata Distant, 1913} (Figs. 3C, 4C, 5D)

Platylomia operculata Distant, 1913: 559 [TL: Indochina]; Distant, 1917: 101; Metcalf, 1963: 623; Boulard, 2005: 36; Sanborn et al., 2007: 23; Lee, 2008: 17; Pham \& Yang, 2009: 15.

Platylomia radha: Distant, 1917: 101; Metcalf, 1963: 623; Chou et al., 1997: 255; Beuk, 1998: 152; Pham, 2004: 64 (nec Distant, 1881).

Material examined: Vinh Phuc: $2 \hat{\jmath}, 1+$ Tay Thien, Dai Dinh, Tam Dao, 500m,

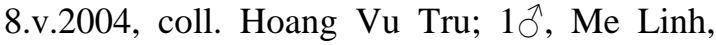
$350 \mathrm{~m}$, 13.i.2000, coll. Hoang Vu Tru, 3q, same locality, ML2220, ML2243, ML2286, 4.vi.2010, 13.vi.2010; 19, Tam Dao NP, 1,000 m, 25-28.vii.2011, coll. Pham Hong Thai; Thua Thien-Hue: $3 \hat{\alpha}$, Bach Ma NP, 1,200 m, 9.vi.2002, coll. Ta Huy Thinh; 4, same locality, 16.vii.2011, coll. Pham Hong Thai; Quang Nam: 20, Lo Xo pass, Phuoc My, Phuoc Son, 1,025 m, Ho.0974, Ho.0975, 1.v.2005; Gia Lai: 1 $\sigma^{\text {, }}$, Dak Roong, Kbang, 1,088 m, Ho.2.0049, light trap, 8.vi.2011. coll. Hoang Vu

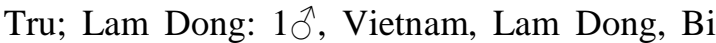
Doup massif, Da Lat $3 \mathrm{~km}$ under Hon Giao, 11.vi.2008, light trap, pond and river bank, $1,548 \mathrm{~m}, \quad 12^{\circ} 10.712^{\prime} \mathrm{N}, \quad 108^{\circ} 42.370^{\prime} \mathrm{E}$, coll. A.Soulier-Perkins (MNHN); 29, Vietnam, Lam Dong, Bi Doup massif, Da Lat $3 \mathrm{~km}$ Hon Giao, 12.vi.2008, light trap, rain forest, $1,567 \mathrm{~m}$, 12011.262'N, 108042.851'E, coll. A. SoulierPerkins (MNHN).

Distribution: Vietnam (Lao Cai, Vinh Phuc, Thanh Hoa, Thua Thien-Hue, Gia Lai, and Lam Dong), China (Yunnan, Guangxi, Jiangxi and Hainan), Myanmar, Laos, Cambodia and Thailand.

\section{DISCUSSION}

The new species differs from Platylomia operculata in the length and shape of operculum that reaching posterior margin sternite $\mathrm{V}$ and apex rounded, while $P$. operculata has operculum extending passing sternite $\mathrm{V}$ and apex acute angled.

Platylomia duffelsi is distinguishable from $P$. bocki and P. malickyi by the structure of pygofer, with basal lobes of pygofer well developed and distinctly prominent in $P$. duffelsi and basal lobe of pygofer not well developed and distinctly prominent in $P$. bocki and $P$. malickyi.

Acknowledgments: We thank Prof. Ta Huy Thinh, Mr. Hoang Vu Tru and MSc. Tran Thieu $\mathrm{Du}$ (Institute of Ecology and Biological Resources, Hanoi) for assistance with field work sharing of specimens and data, Dr. Jérôme Constant (IRSNB), for the grant support to the first author. The grant issued by the capacity building Programme of the Belgian Global Taxonomic Initiative National Focal Point that runs with financial support from the Belgian Directorate-General for Development Cooperation. The present study was partially supported by National Foundation for Science and Technology Development (NAFOSTED106.12-2012.63), Vietnam, the International Foundation for Science (IFS-No D/5181-1), Sweden, and the Nagao Natural Environment Foundation, Japan. The first author thank to IDEA WILD for the donation of equipments for this study. This study would not have been possible without the help of Dr. Thierry Bourgoin, Dr. Jérôme Sueur and Dr. Adeline Soulier-Perkins (The Museum National d'Histoire Naturelle, Paris) kindly allowed me to access to MNHN collection, and the support from The Museum National d'Histoire Naturelle, Paris.

\section{REFERENCES}

1. Barbier Y., Rasmont P., 2000. Carto FaunaFlora 2.0. Guide d'utilisation. Université de Mons Hainaut, Mons, Belgique, 59 pp.

2. Beuk P. L. Th., 1998. Revision of the radha group of the genus Platylomia Stål, 1870 (Homoptera, Cicadidae). Tijdschrift voor entomologie, 140: 147-176.

3. Boulard M., 2003. Contribution à la connaissance des cigales thaïlandaises 
incluant la description de quatre espèces nouvelles (Rhynchota, Cicadoidea, Cicadidae). Revue française d'entomologie, 25: 171-201.

4. Boulard M., 2005. Données statutaires et éthologiques sur des cigales thaïlandaises, incluant la description de huit espèces nouvelles, ou mal connues. Ecole Pratique des Hautes Etudes, Travaux du Laboratoire Biologie et Evolution des Insectes Hemipteroidea, 15: 5-57.

5. Chou I., Lei Z., Li L., Lu X., Yao W., 1997. The Cicadidae of China (Homoptera: Cicadoidea). Ilustrataj Insectfaunoj, 2. Tianze Eldoneio, Hong Kong, 10+380+5 pp., 4+16 pls. (In Chinese with English summary).

6. Distant W. L., 1882. Contributions to a knowledge of the Rhynchotal fauna of Sumatra. Entomologist's Monthly Magazine, 19: 156-160.

7. Distant W. L., 1913. On some recently received Rhynchota. Ann. and Mag. Nat. Hist., 12(8): 556-563.

8. Distant W. L., 1917. The Homoptera of Indo-China. The Annals and Magazine of Natural History, 19(8): 100-104.

9. Guérin-Méneville F. E., 1834. Insectes. In: Bélanger, M. C., Voyage aux IndesOrientales, par le nord de l'Europe, les provinces du Caucase, la Géorgie, l'Arménie et la Perse, suivi de détails topographiques, statistiques et autres sur le Pégou, les Isles de Java, de Maurice et de Bourbon, sur le Cap-de-Bonne-Espérance et Sainte-Hélène, pendant les années $1825,1826,1827,1828$ et 1829 , publié sous les auspices de LL. EE. MM. les Ministres de la Marine et de
l'Intérieur, zoologie. H. Bertrand, Paris, pp. 441-512, pls. 1-5.

10. Lee Y. J., 2008. A checklist of Cicadidae (Insecta: Hemiptera) from Vietnam, with some taxonomic remarks. Zootaxa, 1787: 127.

11. Metcalf Z. P., 1963. General catalogue of the Homoptera, fascicle VIII, Cicadoidea, part 1. Cicadidae. section II. Gaeninae and Cicadinae. North Carolina State College, Raleigh, pp. 587-919.

12. Moulds M. S., 2005. An appraisal of the higher classification of cicadas (Hemiptera: Cicadoidea) with special reference to the Australian fauna. Records of the Australian Museum, 57: 375-446.

13. Pham H. T., Yang T. J., 2009. A contribution to the Cicadidae fauna of Vietnam (Hemiptera: Auchenorrhyncha), with one new species and twenty new records. Zootaxa, 2249: 1-19.

14. Pham H. T., 2004. The cicadas genera Pomponia Stal, 1866; Dundubia Amyot \& Serville, 1843 and Platylomia Stal, 1870 (Cicadidae: Cicadinae) from some national parks and nature reserves in Vietnam. Journal of Biology, 26: 61-65 (In Vietnamese with English summary).

15. Sanborn A. F., Phillips P. K., Sites R. W., 2007. Biodiversity, biogeography, and bibliography of the cicadas of Thailand (Hemiptera: Cicadoidea: Cicadidae). Zootaxa, 1413: 1-46.

16. Stål C., 1870. Hemiptera insularum Philippinarum.-Bidrag till Philippinska öarnes Hemipter-fauna. Öfversigt af Kongl. Vetenskaps-akademiens förhandlingar, 27: 607-776. 


\title{
GIỐNG VE SÀU Platylomia Stål, 1870 (Hemiptera: Cicadidae) Ở VIẸT NAM, VỚI MÔ TẢ MộT LOÀI MỚI VÀ KHÓA ĐỊNH LOẠI ĐẾN LOÀI
}

\author{
Phạm Hồng Thái ${ }^{1}$, Jérôme Constant ${ }^{2}$
}

${ }^{1}$ Bảo tàng Thiên nhiên Việt Nam, Viện Hàn lâm KH \& CN Việt Nam

${ }^{2}$ Royal Belgian Institute of Natural Sciences, Belgium

\section{TÓM TẮT}

Bài báo mô tả một loài ve sầu mới cho khoa học thuộc giống Platylomia Stål, Platylomia duffelsi sp.n.. Mẫu vật của loài này thu được ở Khu rừng đặc dụng Phia Oắc - Phia Đén, huyện Nguyên Bình, tỉnh Cao Bằng, Việt Nam. Ảnh chụp mẫu con trưởng thành và hình vẽ cấu tạo bộ phận sinh dục của con đực được minh họa. Bài báo còn đưa ra khóa định loại cho 4 loài: Platylomia species: $P$. bocki (Distant), $P$. duffelsi sp. nov., $P$. malickyi Beuk và $P$. operculata Distant dựa vào cá thể đực con trưởng thành ghi nhận có ở Việt Nam. Loài mới Platylomia duffelsi sp. n., thuộc nhóm loài Platylomia radha. Loài mới này được phân biệt với tất cả các loài còn loại của nhóm loài này bởi cấu trúc của bộ phận sinh dục con đực trưởng thành và kích thước cũng như hình thái của operculum. Bộ phận sinh dục con đực nhìn từ phía bụng có chiều dài hơn chiều rộng, với lớp lông tơ dài ở mép bên; thùy gốc của bộ phận sinh dục con đực nhô lên rõ rệt, thùy bên của bộ phận sinh dục con đực nhìn từ phía bụng với mép ở đỉnh thẳng; uncus phân nhánh, thùy uncus kéo dài và nhọn ở đỉnh; dorsal beak sắc nhọn, màu đen hơi nâu; anal styles và anal tube màu nâu tối. Phân bố của các 1「ài thuộc giống Platylomia ở Việt Nam cũng được chỉ rõ trên bản đồ.

Tì khóa: Auchenorrhyncha, Platylomia, cicada, phân bố, loài mới.

Ngày nhận bài: 15-6-2014 